\title{
The Effectiveness of Using L1 in Second Language Classrooms: A Controversial Issue
}

\author{
Khedir A. Almoayidi \\ Department of Linguistics, Macquarie University, Australia; \\ Department of English, Umm Al-Qura University, Saudi Arabia
}

\begin{abstract}
This paper aims to uncover the hidden debate about the efficacy and inefficacy of using mother tongue in second language classroom. Teaching English as a second language is not an easy task to be undertaken. There are many approaches that postulate the optimal strategy for better teaching. As such, numerous researchers in the fields of language teaching and learning hold a belief that the use of $\mathrm{L1}$ in $\mathrm{L2}$ classrooms helps to facilitate learning. However, a significant number of researchers contend that the use of L1 in L2 classroom hinders learning and deprives learners from the exposure to the second language. As such, this paper tries to shed light on both views and to give evidence that using L1 in L2 classroom has a negative impact on $L 2$ learners.
\end{abstract}

Index Terms - mother tongue, second language, language learning

\section{INTRODUCTION}

Learning English is considered essential by many people, and more particularly by those who want to find better jobs or get a good education. For this reason, many countries all over the world have embraced the English language to be the source of their education as well as the language of the curricula. More importantly, the concept of Anglicisation has dominated education and caused many people to stop using their mother tongue in favour of English, more specifically, in classroom instruction for the purpose of immersion. As such, it is found that in many countries the medium language for teaching subjects such chemistry, physics, mathematics and others is English. It is essential to discriminate here between teaching other subjects using English as medium and teaching English as a second or a foreign language, which is the core of this paper to investigate (Ferreira, 2011). The view of using English to teach in classrooms is still a hotly debated issue amongst linguists and researchers. This is due to the other belief that the use of the mother tongue is a helpful and useful facilitator for second language learning, English in particular. Furthermore, through observation and by comparing learners in Saudi Arabia who have been exposed to L1 (Arabic) while learning L2 (English) and those who have been exposed to L2 only, it can clearly be seen that the latter group of learners always outdo the former in all skills. Also, it has been found according to Al-Nofaie (2010) that most learners of English in Saudi Arabia were inclined to be taught in the target language (L2) so that they get the feel of and actually practise using the language. In addition, these Saudi learners pointed that the use of Arabic in their classroom should be decreased. This assumption is still not satisfying to be presented to investigate an issue in which the debate is not clearly decisive and the argument about involving L1 or not in L2 classroom is as the tide of ocean. For example, Atkinson (1987) claimed that the mother tongue is considered advantageous for a great number of learners all over the world because it is strongly tied up with learners' preferred strategies of learning. On the other hand, a significant number of linguists (Turnbull \& Arnett, 2002; Levine, 2003; Nation, 2003; Scott \& de la Fuente, 2008; Littlewood \& Yu, 2009) believe that using the mother tongue in the classroom might hinder second language learning and for this reason it is essential to immerse learners in the second language only.

However, in his inspiring hypothesis of 'comprehensible input', Krashen (1981) argued that the second language should be taught and learned through second language only and the mother tongue should not play a role in this situation. As such, the aim of this paper is to critically shed light on the views of both groups and to find a common ground which might minimise the gap between them and provide evidence upon which a conclusion can be drawn. In other words, this paper will attempt to find an influential answer to the following question: should learners of English as a second or foreign language be exposed to English only or to English and their mother tongue simultaneously?

\section{REVIEW OF LITERATURE}

This part of the paper aims to shed light on the theoretical as well as the empirical studies of those who believe that the L1 is beneficial in teaching the L2 and studies which propose a negative view of the L1 as a hindrance in the teaching of L2. Cook (2001) is considered to be one of the researchers who supported the use of L1 in the L2 classroom. He stated that the L1 equips learners with the language competence they need when the translation method is used. He also argued that even though many teachers work hard to keep their students separated from their mother tongue, students still have a mental link between the two languages. Based on the same logical idea, a new trend of teaching 
developed called the Linguistic Interdependence Hypothesis (Cummins, 2007; Butzkamm \& Caldwell, 2009). This hypothesis suggests that use of the mother tongue by teachers in the classroom is beneficial because, according to this hypothesis, transfer is not always a negative aspect and languages are linguistically interdependent except for a few elements which cannot cause any hindrance in language learning (Jessner \& Cenoz, 2000; Bouvy, 2000; Herdina \& Jessner, 2002). Furthermore, the mother tongue motivates learners of a second language to be active learners and it saves their time and at the same time shapes their conceptualisation of learning (Ellis, 2008; Turnbull, 2002). This view was confirmed by Cook (2002) who claimed that 'given the appropriate environment, two languages are as normal as two lungs' (p. 23).

Such an assumption is widely accepted by those who still support the use of Grammar Translation Method (GTM) in their second or foreign language teaching classrooms. Furthermore, Eldridge (1996) confirmed that it has not been proved empirically that restricting the use of the mother tongue in the classroom will improve learners' efficiency; for this reason it is considered old-fashioned to not include the mother tongue in classroom instruction (Atkinson, 1987). As a final remark, from a theoretical point of view, the use of the mother tongue in classrooms should not be restricted, and it should be used according to the needs of learners as well as the classroom situation (Atkinson, 1993; Weschler, 1997; Nation, 2003; Norman, 2008).

The use of L1 in the L2 classroom has also been the main focus of a significant number of recent empirical studies (Schweers, 1999; Tang, 2002; Bouangeune, 2009; Kavaliauskiene, 2009; Kovacic \& Kirinic 2011; Mahmoudi \& Amirkhiz, 2011; Carson \& Kashihara, 2012; Timor, 2012; Mohebbi \& Alavi, 2014) which have shown that using the mother tongue is considered to be a good tool for teaching English. However, other studies have looked at L1 as an obstacle when learning L2 so it should not be used in the classroom. Turnbull (2001), for instance, responded to Cook's view and stated that the use of the mother tongue by the teacher is not beneficial to L2 learners. This was also the view of McDonald (1993) when he argued that the classroom is the only suitable context where learners can be exposed to the L2 and if teachers use the L1, learners will have no opportunity to experience real use of the L2. This is also premised on the assumption that learners of the L2 will be disinclined to practise the L2 in a classroom where teachers are inclined to use the L1 (Ellis, 2008).

In addition, Krashen's 1981 comprehensible input hypothesis is considered to be an influential concept. This hypothesis proposes that the L2 should be taught through the L2 only and any underestimation of this will negatively affect the L2 learners' progress. To illustrate, teaching of L2 should be conducted in L2 not only to explain the rules of the language, but even for the communication between a teacher and his/her students. Aligned with Krashen's view, Swain (1985) proposed the comprehensible output hypothesis which suggests that learners of L2 need more activation of their language in the classroom rather than receiving instruction and rules and, as such, the L2 can help in this activation. This suggests that the L2 should be used extensively in classrooms in order to help learners to have full exposure to the L2 in various contexts (Littlewood \& Yu, 2011). Other studies have also shown that it is essential to immerse learners in the L2 rather than using their mother tongue. This can be seen in various recent papers and reviews by (Turnbull \& Arnett, 2002; Levine, 2003; Nation, 2003; Scott \& de la Fuente, 2008; Littlewood \& Yu, 2009) in which the researchers argue that learners of a second language should have exposure to the L2 to obtain the most benefit.

\section{DISCUSSION}

Scrutinising previous studies shows that the challenging point upon which researchers have based their arguments is whether use of the L1 facilitates or hinders the learning of a second language. This controversy is often discussed and will remain an issue since each group of researchers has evidently provided empirical data to support the view they believe in. In regard to the advocates of using the mother tongue as a facilitator in the L2 classroom, they have developed this view as a result of dissatisfaction with the direct method and in favour of the Grammar Translation Method (GTM) which emerged in the late nineteenth century (Brown, 2000). The purpose of using GTM was to utilize translation as a technique for teaching and this saves teachers as well as learners' time trying to find the meaning of certain problem words in any context and any language that learners exposed to (Esmaiel, 2015). In this regard, the course of using L1 in class has returned to be influential to be implemented while teaching English as a second language. To support their view they have proposed many reasons that the L1 should be used in the L2 classroom. Culture and identity, for instance, have been taken into account as Schweers (1999) pointed out in the study he conducted on Spanish native speakers who were learning English as a foreign language. Based on the classrooms recording and the questionnaire, he discovered that students found it easier to cope with the L2 teacher if he/she can speak their mother tongue because this indicates how such a teacher appreciates the students' mother tongue. This claim was also found in Nation's (2003) who believed that the mother tongue of students should be respected by their teacher and should never be underestimated in any situation.

Another reason proposed by L1 advocates is that the use of the mother tongue is helpful to eliminate students' anxiety in L2 classrooms. According to Brown (2000), it is known that adult learners are more rigid in learning than children and they are more inclined to be cautious when learning. As such, the use of L1 is essential to minimise language learning anxiety in classrooms (Meyer, 2008). Moreover, Nation (2003) explains that using L2 only in the classroom can be an obstacle which might make learners feel hesitant to use the L2, especially if they are not well equipped with it. This also was discovered by Nunan (1999) who explained that when teachers in China forced their 
students to not use their L1 in order to practise the L2, this unfortunately did not help them to either speak their mother tongue or the second language in the classroom.

The final justification, which is considered to be the motivation behind using L1, is that using translation saves time. This is supported by many researchers who suggest that instead of wasting time defining and elaborating on the meaning of certain words to help learners, L1 translation is considered the best alternative (Atkinson, 1987; Brown, 2000; Tudor, 1987; Cook, 2001; Tang). Furthermore, translation is looked at as skills that learners should learn. Ross (2000), notes that translation is now considered to be a key skill in its own right that should be included with the other four skills of listening, speaking, reading and writing. Thus, it should be implemented in classrooms as a tool for comprehension as well as communication. Such a claim was also made by Mahmoud (2006) who stated that using translation in classrooms assists L2 learning and motivates autonomous learning.

As a final remark on these suggestions, the proponents of L1 usage in classrooms have many other reasons which stress the importance of using L1. However, most of these studies as well as claims cannot be overgeneralized to other contexts where the purpose of learning as well as the context is of learning are different. Teaching English to international students in Australia, America or Britain, for instance, requires multilingual teachers in order to use the L1 of each student who comes from Chinese, Spanish, Arabic, Malaysian, Indonesian, Japanese backgrounds to clarify certain element of the language. This is not impossible, but it is an arduous to be attainable and at the same time will waste time other than to save time.

By contrast, the above-mentioned justifications for the use of L1 in classrooms can be refuted from various perspectives to show that the best way to teach any language is through its components. This rejection rests on the belief of proponents of the direct method who argue that learners should learn the L2 in a similar way to the way they learnt their mother language (Yu, 2000). To illustrates, learners must be exposed to the L2 not only to teach language skills but to be involved in language communication in order to comment, to enquire, to ask and to clarify. As such, the monolingual approach was noted to be the base from which other concepts and beliefs stem (Howatt, 1984).

In line with this, Sharma (2006) argued that the use of L2 only is classrooms stems from the rationale that this exposure assists learners to rapidly learn the language and helps them integrate it in various activities. Under this rationale the learning of the second language is not only to pass certain exam, conversely, the aim is to learn a language for better understanding of other cultures, to live in another country or for instrumental purposes. These purposes indeed necessitate the need to expose these learners into L2 excessively. Arguably, the purpose of learning, the context and the type of learners can influence what method to be appropriate for teaching. In fact, this is true in learning English as a second language and it becomes an essential factor when English is taught as a foreign language, such as in Saudi Arabia to which country the researcher belongs. From my experience as a language lecturer there, using L2 in the classroom is considered more beneficial and helpful for learners to progress in the learning of English. It is essential because the language of the society there is Arabic and the only chance for English learners to practise and to be exposed to the language is in the classroom; thus if the instructor is inclined to use L1, learners will be deprived of the chance of real learning of English especially for those who learn a language as life skill. This observation is supported by Turnbull (2001) who argued that when teachers of L2 depend on L1 as a tool for learning, their learners will have no benefit and this can be seen when such teachers are the only channel of knowledge for these learners. Similarly, Wong (2010) pointed out that learners of English in Hong Kong were observed to prefer English only in the classroom which in turn positively influenced their acquisition of English. In support of this view, Kharma and Hajjaj (1989) conducted an early empirical study using the methods of observation and questionnaire on Arab learners and found that L1 should be avoided when teaching L2 because the goal of teaching L2 is to make learners acquire L2-compentence; thus the use of L1 will hinder any progress in achieving this goal. This claim, to some extent, can be true, but if these learners' purpose of learning is to pass the course only, then L1 one is essential to facilitate learning not to hinder it.

Indeed, Cook (2001), who is considered to be amongst the pioneering proponents of L1, once pointed that the use of L1 might posit, in some circumstances, an obstacle to L2 learners' exposure. In this regard, it was noted that those teachers who tended to use L1 (Arabic) in their classrooms neglected teaching the language and tended to teach about the language. This means that instead of involving their learners in classroom activities they became language-centered teachers because they wasted learners' time teaching about English rather than encouraging the learners' to use the language in various activities. Additionally, it can be pointed here that some teachers tend to use L1 excessively in L2 classrooms in order to conceal their weakness and poor proficiency in L2; however, this needs to be proven empirically in further studies to become a tangible argument.

In addition to what has been mentioned above, the advocates of using L2 only in classrooms have postulated more than one reason to reject the use of L1 in classrooms. One of these is that when teachers tend to use the mother tongue as a tool to simplify L2 input, this will tend to become a habit that cannot be changed and this habit will increase to cover most L2 input. This assumption is revealed in the study of Voicu (2012) who claimed that the inclination to use L1 might encourage teachers as well as learners to form a habit for resolving any difficulty. This is also explained by MacDonald (1993) that there is no need for teachers to turn to L1 in order to alleviate difficulty for learners because this can hinder learners' L2 progression.

The foregoing discussion implies that many studies suggest that using L2 (the target language) in classrooms aids the progress and achievement of learners (Turnbull \& Arnett, 2002). This indicates that using L2 only is essential to push 
learners toward the second language environment as well as culture rather than confining them within the mother tongue.

\section{CONCLUSION AND RECOMMENDATION}

Throughout this paper the researcher's aim has been to uncover and investigate the debate about whether a second language should be taught using the mother tongue or without it. A significant number of studies have been presented to trace the history of this debate and examine the evidence used to support both views. Although many studies have shown that using L1 in classrooms is considered a good method to pave the way for learners to acquire a second language, this paper has mentioned many studies which claim that the best way to teach English is through English only and that the mother tongue should be avoided for better results. It can be clearly seen that this will remain a vexed debate amongst linguists, educators and researchers since opinions on this issue waver from one aspect to another and from one educational community to another. This also depends on various factors such as the context of learning, the type of learners, teachers' L2 proficiency, students' purposes of learning the second language and the regulations which are postulated by governments toward teaching foreign languages in general. Thus, it should be taken into account that supporting one view does not mean full rejection of the other since knowledge is believed to be relative.

However, as a point of view which is based on the evaluation of each polar in regard of either using L1 in classroom or not, it can be argued that exposing learners to L2 only is the appropriate teaching method for most of learners and in many contexts. Regardless of learners' purposes to learn English to pass certain level or to have it as a life skill and regardless of the context of learning and teaching, the exposure to L2 only in classroom makes learning profitable, enjoyable and good experience for learners to express their thought in new language.

As a final remark, future researchers should conduct new studies using a longitudinal method and it must be conducted in various contexts in order to compare and contrast their results for better understanding of the new attitudes toward the use of L1 and L2 in classrooms. These attitudes must be obtained from students, teachers, curriculum designers, decision makers and the parents of learners.

\section{REFERENCES}

[1] Al-Nofaie, H. (2010). The Attitudes of Teachers and Students towards Using Arabic in EFL Classrooms in Saudi Public Schools: A Case Study. Novitas-Royal, 4(1), 64-95.

[2] Atkinson, D. (1987) The mother tongue in the classroom: a neglected resource?. ELT Journal, 41(4), 241-247.

[3] Atkinson, D. (1993). Teaching monolingual classes. London: Longman.

[4] Bouangeune, S. (2009) Using L1 in teaching vocabulary to low proficiency level students: A case study at the University of Laos. English Language Teaching Journal, 2(3), 186-193.

[5] Bouvy, C. (2000). Towards the construction of a theory of cross-linguistic transfer. In J. Cenoz \& U. Jessner (Eds.), English in Europe: The acquisition of a third language (pp. 143-55). Clevedon, England: Multilingual Matters.

[6] Brown, H. D. (2000). Principles of language learning and teaching (4th edn.). White Plains, NY: Addison Wesley Longman, Inc.

[7] Butzkamm, W. \& Caldwell, J. (2009). The bilingual reform: A paradigm shift in foreign language teaching. Tübingen, Germany: Gunter Narr Verlag.

[8] Carson, E., \& Kashihara, H. (2012). Using the L1 in the L2 classroom: The students speak. The Language Teacher, 36(4), 4148.

[9] Cook, V. (2001). Using the first language in the classroom. Canadian Modern Language Review, 57(3), 402-423.

[10] Cook, V. (Ed.). (2002). Portraits of the L2 user. Clevedon, England: Multilingual Matters.

[11] Cummins, J. (2007). Rethinking monolingual instructional strategies in multilingual classrooms. Canadian Journal of Applied Linguistics, 10(2), 221-240.

[12] Eldridge, J. (1996). Code-switching in a Turkish secondary school. ELT Journal, 50(4), 303-311.

[13] Ellis, R. (1994). The study of second language acquisition. Oxford, England: Oxford University Press.

[14] Esmaeil, H. A. (2015). Comparative study of Grammar Translation Method (GTM) and Communicative Language Teaching (CLT) in language teaching methodology. International Journal of Science and Research Methodology, 1. (3), 16-25.

[15] Ferreira, J. G. (2011). Teaching Life Sciences to English second language learners: What do teachers do?. South African Journal of Education, 31(1), 102-113.

[16] Howatt, A. P. R. (1984). A history of English language teaching. Oxford: Oxford University Press.

[17] Jessner, U., \& Cenoz, J. (2000). Expanding the score: Sociolinguistic, psycholinguistic and education aspects of learning English as a third language in Europe. In J. Cenoz \& U. Jessner (Eds.), English in Europe: The acquisition of a third language (pp. 248-260). Clevedon, England: Multilingual Matters.

[18] Kavaliauskiené, G. (2009). Role of mother tongue in learning English for specific purposes. ESP World, 1(22), 1-12.

[19] Kharma, N. and Hajjaj, A. (1989), Use of the mother tongue in the ESL classroom. International Review of Applied Linguistics in Language Teaching, 27(3), 223-235.

[20] Kovacic, A., \& Kirinic, V. (2011). To use or not to use: First language in tertiary instruction of English as a Foreign Language. Paper presented at the 1st International Conference on Foreign Language Teaching and Applied Linguistics, Sarajevo.

[21] Krashen, S.D. (1981). Second language acquisition and second language learning. Oxford: Pergamon Press Inc.

[22] Krashen, S.D. (2003). Explorations in language acquisition and use. Portsmouth: NH: Heinemann.

[23] Larsen-Freeman, D. (2001). Techniques and principles in language teaching. Oxford University Press. Oxford 
[24] Levine, G. S. (2003). Student and instructor beliefs and attitudes about target language use, first language use, and anxiety: Report of a questionnaire study. The Modern Language Journal, 87(3), 343-364.

[25] Littlewood, W. \& Yu, B. (2009). First language and target language in the foreign language classroom. Language Teaching, 44(1), 64-77.

[26] Littlewood, W. \& Yu, B. (2011). First language and target language in the foreign language classroom. Language Teaching, 44(1), 64-77. Retrieved from http://dx.doi.org/10.1017/S0261444809990310.

[27] Mahmoud, A. (2006), Translation and foreign language reading comprehension: A neglected didactic procedure. English Teaching Forum, 44(4), 28-33.

[28] Mahmoudi, L., \& Amirkhiz, S. (2011). The use of Persian in the EFL classroom:-The case of English teaching and learning at pre-university level in Iran. English Language Teaching, 4(1), 135-140.

[29] McDonald, C. (1993). Using the target language. Cheltenham, UK: Mary Glasgow.

[30] Meyer, H. (2008). The pedagogical implications of L1 use in the L2 classroom. Maebashi Kyoai Gakuen College Ronsyu, 8 , 147-159.

[31] Mohebbi, H., \& Alavi, S. M. (2014). Teachers' first language use in second language learning classroom context: A Questionnaire-based study. Bellaterra: Journal of Teaching and Learning Language and Literature, 7(4), 57-73.

[32] Nation, P. (2003) Nation, P. (2003). The role of the first language in foreign language learning. Asian EFL Journal, 5(2), 1-8.

[33] Norman, J. (2008). Benefits and drawbacks to L1 use in the L2 classroom. Paper presented at the JALT2007 Conference, Tokyo.

[34] Nunan, D. (1999). Second language teaching \& learning. Boston: Heinle \& Heinle Publishers.

[35] Richards, J. C. and Rodgers, T. S. (1982). Method: Approach, design and procedure. TESOL Quarterly, 16, 153-68.

[36] Ross, N. J. (2000). Interference and intervention: Using translation in the EFL classroom. Modern English Teacher, 9(3), 61-66.

[37] Schweers, W. Jr. (1999). Using L1 in the L2 classroom. English Teaching Forum, 37(2), 6-9.

[38] Nation, P. (2003). The role of the first language in foreign language learning. Asian EFL Journal, 5(2). Retrieved from http://asian-efljournal.com/june_2003_PN.phpz.

[39] Scott, V. M., \& de la Fuente, M. J., (2008). What's the problem? L2 learners' use of the L1 during consciousness-raising, form-focused tasks. The Modern language Journal, 92(1), 100-113.

[40] Sharma, K. (2006), Mother tongue use in English classroom. Journal of NELTA, 11(1-2), 80-87.

[41] Swain, M. (1985). Communicative competence: Some roles of comprehensible input and comprehensible output in its development. In S. Gass \& C. Madden (Eds.), Input and Second Language Acquisition (pp. 235-254), Rowley, MA: Newbury House.

[42] Tang, J. (2002). Using L1 in the English classroom. English Teaching Forum, 40(1), 36- 43.

[43] Timor, T. (2012). Use of the mother tongue in teaching a foreign language. Language Education in Asia, 3(1), 7-17.

[44] Tudor, I. (1987). Using translation in ESP. ELT Journal, 41(4), 268-273.

[45] Turnbull, M. (2001). There is a role for the L1 in second and foreign language teaching, but ... The Canadian Modern Language Review, 54(4), 531-540.

[46] Turnbull, M., \& Arnett, K. (2002). Teachers' uses of the target and first languages in second and foreign language classroom. Annual Review of Applied Linguistics, 22, 204-218.

[47] Üstünel, E., \& Seedhouse, P. (2005). Why that, in that language, right now? Code-switching and pedagogical focus. International Journal of Applied Linguistics, 15(3), 302-325.

[48] Voicu, C. G. (2012). Overusing mother tongue in English language teaching. International Journal of Communication Research, 2(3), 212-218.

[49] Weschler, R. (1997). Uses of Japanese (L1) in the English classroom: Introducing the functional translation method. The Internet TESL Journal, 3(11), On-line. Available at http://iteslj.org/articles/Weschler-usingL1.html.

[50] Wong, M. H. R. (2010). The effectiveness of using English as the sole medium of instruction in English classes: Student responses and improved English proficiency. Porta Linguarum, 13, 119-130.

[51] Yu, W. (2000). Direct method. In M. Byram (Ed.), Routledge encyclopedia of language teaching and learning (pp. 176-178). New York: Routledge.

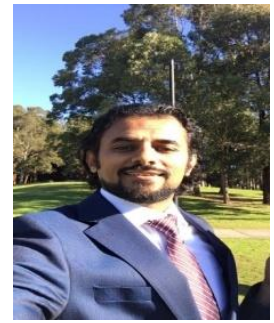

Khedir Attaf Almoayidi was born in Al-Qunfudhah, Saudi Arabia. He received two masters in Linguistics; one from King Abdulaziz University and the other is from Macquarie University. He is currently doing his $\mathrm{PhD}$ in Linguistics, Macquarie University. He works as a lecturer in the Department of English, AlQunfudhah University College. His research interests include phonetics and phonology, pronunciation, dictionaries and second language learning. 